\title{
Production and characterisation of monoclonal antibodies to outer-membrane-protein antigens of Vibrio cholerae 01
}

\author{
S. KABIR* \\ Department of Immunology, Karolinska Institute, Stockholm, Sweden
}

\begin{abstract}
Summary. Monoclonal antibodies (MAbs) were raised against the major, 46-48-Kda outermembrane proteins of Vibrio cholerae $\mathrm{O} 1$. The hybridoma clones were screened by enzymelinked immunosorbent assay (ELISA) with cell-surface proteins of $V$. cholerae $\mathrm{O} 1$ as the coating antigen. Four hybridomas, which secreted anti- $V$. cholerae cell-surface-protein antibodies, were subcloned by limiting dilution and obtained as ascites in vivo. A MAb of the $\mathrm{IgG}_{1}$ subclass was isolated in good yield from the murine ascites by affinity chromatography with recombinant protein G-Sepharose 4B. It gave positive reactions, as determined by ELISA, against cell-surface proteins prepared from both biotypes (classical and $\mathrm{El}$ Tor) and both serotypes (Ogawa and Inaba) of $V$. cholerae O1. The MAb did not have any reactivity towards $V$. cholerae lipopolysaccharide preparations. Immunoblotting studies were performed on cell-surface proteins separated by one-dimensional sodium dodecyl sulphate-polyacrylamide gel electrophoresis (1D SDS-PAGE) and also by two-dimensional (2D) electrophoresis with iso-electric focusing in the first dimension followed by SDS-PAGE in the second dimension. When proteins were separated by ID SDS-PAGE, only one band at $46-48 \mathrm{Kda}$ reacted with the MAb. This protein appeared to consist of two narrowlyspaced and cross-reactive bands when a nitrocellulose blot, obtained by 2D SDS-PAGE, was exposed to the MAb.
\end{abstract}

\section{Introduction}

The outer membrane of Vibrio cholerae $\mathrm{O} 1$ contains a number of proteins (OMPs) in the size range 13$66 \mathrm{Kda}$; their relative compositions and proportions depend on the conditions of growth. ${ }^{1,2}$ Many of these proteins are exposed on the cell surface, as demonstrated by immuno-electronmicroscopy and radioiodination techniques ${ }^{3,4}$ and have been found to be immunogenic both in man and in experimental animals. ${ }^{1,2,5}$ Antisera to the OMPs gave immunoprecipitation reactions with OMPs prepared from both biotypes (classical and El Tor) and both serotypes (Ogawa and Inaba) of $V$. cholerae O1, suggesting the presence of common protein antigens. ${ }^{1}$ However, such polyclonal sera had to be absorbed with lipopolysaccharide (LPS) in order to exclude anti-LPS antibodies. Therefore, there is a need to produce specific antibodies to OMPs under conditions in which antibodies to LPS are not generated.

Sciortino et al. ${ }^{6}$ obtained monoclonal antibodies (MAbs) against various components of $V$. cholerae such as LPS and OMPs by immunising mice with outer-membrane preparations. These authors used crude tissue-culture supernates instead of purified MAbs for immunoblotting studies. They obtained

Received 12 April 1990; revised version accepted 15 Aug. 1990. * Correspondence should be sent to Dr. S. Kabir, Tobakspinnargatan 5, 2 TR, 11736 Stockholm, Sweden. simultaneously several clones and, in some cases, these antibodies showed broad-range specificities by reacting with a series of protein bands of different molecular weights. It is possible that impurities present in the crude tissue-culture supernates might have contributed to the non-specific binding in immunoblots. The present investigation was initiated to produce hybridomas against a purified OMP preparation and to use purified MAbs for immunoblotting studies.

Earlier, by use of both radiolabelled protein $A$ and immuno-electronmicroscopy techniques with protein A-gold particles, it was demonstrated that treatment of $V$. cholerae with EDTA/ $\mathrm{NaCl}$ extracted proteins which were localised on the cell surface ${ }^{3,7}$ When these proteins were treated with a mildly anionic detergent such as sodium deoxycholate (DOC), the insoluble pellet was significantly enriched in the major protein band of $46-48 \mathrm{Kda}$. Previous studies, based on immuno-electronmicroscopy techniques, also had suggested that this major protein component was exposed on the cell surface of $V$. cholerae. ${ }^{3}$ The aim of the present investigation was to produce and to characterise MAbs to this protein.

\section{Materials and methods}

\section{Bacterial strains}

$V$. cholerae strains 395 (Ogawa, classical), 569B (Inaba, classical), W-13021 (Ogawa, El Tor) and N- 
16961 (Inaba, El Tor) were used. Cultures were grown in peptone water $3 \% \mathrm{w} / \mathrm{v}, \mathrm{pH} 7.4$ (Difco) with continuous shaking at $37^{\circ} \mathrm{C}$ and harvested at the stationary phase of the growth.

\section{Extraction of cell-surface proteins of $V$. cholerae}

Cell-surface proteins were extracted from $V$. cholerae cells with EDTA/ $\mathrm{NaCl}$ as described by $\mathrm{Kabir}{ }^{7}$ Briefly, $2 \mathrm{~g}$ (wet weight) of $V$. cholerae cells were washed twice with cold $\left(4^{\circ} \mathrm{C}\right) 0.1 \mathrm{M} \mathrm{NaCl}$ and then with cold EDTA/ $\mathrm{NaCl}(5 \mathrm{ml} ; 0.12 \mathrm{M}$ EDTA, $0.77 \mathrm{M}$ $\mathrm{NaCl}, \mathrm{pH} 7 \cdot 2$ ). The combined extracts obtained after centrifugation $(20000 \mathrm{~g}, 30 \mathrm{~min})$ were concentrated by negative pressure dialysis against $0.01 \mathrm{M}$ phosphatebuffered saline (PBS, pH 7.2) and again centrifuged for $15 \mathrm{~min}$. The resultant supernate was used for further investigation. A portion of the supernate was lyophilised. The material (35 mg, dry weight) was treated with sodium deoxycholate (DOC; $0.5 \% \mathrm{w} / \mathrm{v}$, $5 \mathrm{ml}$ ) for $16 \mathrm{~h}$ at room temperature and centrifuged at $85000 \mathrm{~g}$ for $1 \mathrm{~h}$. The pellet was taken up in water, dialysed extensively against water for $24 \mathrm{~h}$ and lyophilised.

\section{Immunisation schedule}

An emulsion of DOC-insoluble cell-surface proteins of $V$. cholerae strain 395 was made in Freund's complete adjuvant (FCA; Difco) at a concentration of $20 \mu \mathrm{g}$ of protein in $300 \mu \mathrm{l}$ of FCA. BALB/c mice were immunised with this emulsion partially in foot pads and partially subcutaneously. Volumes of $150 \mu \mathrm{l}$ of the emulsion were injected at each injection site. On days 10 and 20, mice were given booster injections of similar amounts of the protein suspended in Freund's incomplete adjuvant. Four days after the last immunisation, mice were killed and immune lymphocytes were isolated from their spleens for fusion with myeloma cells.

\section{Fusion procedure}

Spleen cells from immunised mice and hypoxanthine-guanine phosphoribose transferase-deficient mouse myeloma cells (Sp 2/0-X63) were mixed together in a ratio of 4:1 in Dulbecco modified Eagle's medium (DMEM) and centrifuged at $200 \mathrm{~g}$ for $10 \mathrm{~min}$. The pellet was equilibrated at $37^{\circ} \mathrm{C}$ for $1 \mathrm{~min}$ and then $1 \mathrm{ml}$ of polyethylene glycol $50 \% \mathrm{w} / \mathrm{v}$ was added slowly over a period of $1 \mathrm{~min}$. The mixture was further incubated for $90 \mathrm{~s}$ at $37^{\circ} \mathrm{C}$ when fusion was stopped by adding slowly DMEM $(15 \mathrm{ml})$. The mixture was centrifuged at $400 \mathrm{~g}$ for $15 \mathrm{~min}$, washed once with DMEM and was distributed in flat-bottomed 96-well microtitration plates (Coster, Cambridge, MA, USA) at $2 \times 10^{5}$ cells/well in DMEM containing hypoxanthine, aminopterin, thymidine (HAT), 2 mM L-glutamine and penicillin-streptomycin (pen-strep). ${ }^{8}$ All wells contained peritoneal macrophages $\left(0.5 \times 10^{4}\right.$ cells) from non-immune mice as feeder layers. The DMEM-HAT medium was changed after 3 days. On the seventh day the medium was replaced by DMEM containing hypoxanthine, aminopterin (HT), 2 mM Lglutamine and pen-strep. ${ }^{8}$ After 10 days supernates from wells containing growing clones were tested by ELISA for antibody to DOC-insoluble cell-surface proteins of $V$. cholerae. Antibody-secreting hybrids were cloned thrice by limiting dilution in 24-well plates with macrophages as feeder cells. ${ }^{9}$

\section{Antibody detection}

Supernates were screened for the presence of antibodies to DOC-insoluble cell-surface proteins by ELISA. Polystyrene microtitration plates were coated with $100 \mu \mathrm{l}$ of DOC-insoluble cell-surface proteins $(10 \mu \mathrm{g} / \mathrm{ml}$ in $0.05 \mathrm{M}$ carbonate buffer, $\mathrm{pH} 9.6)$ per well. Plates were incubated at room temperature for $24 \mathrm{~h}$ to allow adsorption of the antigen and then washed with PBS containing Tween 20 (Sigma) $0.05 \mathrm{w} / \mathrm{v}$. Plates were incubated with bovine serum albumin (BSA; $3 \% \mathrm{w} / \mathrm{v}, 100 \mu \mathrm{l} / \mathrm{well}$ ) for $1 \mathrm{~h}$ at room temperature, then were washed and the supernates were added. After $2 \mathrm{~h}$ at $37^{\circ} \mathrm{C}$, the plates were washed and rabbit antimouse immunoglobulins were added. After $1 \mathrm{~h}$ at room temperature, plates were washed and then incubated for $1 \mathrm{~h}$ at $37^{\circ} \mathrm{C}$ with protein $\mathrm{A}$ coupled to alkaline phosphatase ( 1 in 1000 dilution in PBS). The plates were then washed and the substrate ( $p$ nitrophenyl phosphate $1 \mathrm{mg} / \mathrm{ml}$ in diethanolamine) was added. Absorbance was measured at $405 \mathrm{~nm}$ by a Titertek Multiskan automatic plate reader (Flow Laboratories).

\section{Production of ascitic fluid containing $M A b$}

Cloned hybridoma cells were expanded by growth in DMEM. Hybridoma cells $\left(5 \times 10^{6}\right)$ were injected intraperitoneally into BALB/c mice which had been primed 2-4 weeks earlier with a $0 \cdot 5-\mathrm{ml}$ injection of pristane (2, 6, 10, 14-tetramethylpentadecane; Sigma). Ascitic fluids, normally produced after 10-14 days, were aspirated, centrifuged at $1500 \mathrm{~g}$ for $10 \mathrm{~min}$ and stored at $-70^{\circ} \mathrm{C}$

\section{Purification of $M A$ Abs by affinity chromatography}

(i) Protein A-Sepharose 4B. Ascitic fluid (1 ml) was dialysed overnight at $4^{\circ} \mathrm{C}$ against $1.5 \mathrm{M}$ glycine, $3 \mathrm{M}$ $\mathrm{NaCl}$ adjusted to $\mathrm{pH} 8 \cdot 9$. The material was centrifuged at $10000 \mathrm{~g}$ for $10 \mathrm{~min}$ and the supernate was applied to a column $(5 \times 0.7 \mathrm{~cm})$ of protein A-Sepharose 4B (Pharmacia Fine Chemicals, Uppsala, Sweden) equilibrated with $1.5 \mathrm{M}$ glycine, $3 \mathrm{M} \mathrm{NaCl}, \mathrm{pH} 8.9$. The column was eluted with $0 \cdot 1 \mathrm{M}$ sodium citrate buffer pH 6.0, and the column effluent was monitored spectrophotometrically at $280 \mathrm{~nm}$ with an LKB Uvicord.

(ii) Protein G-Sepharose 4B. Ascitic fluid (1 ml) was 
dialysed overnight at $4^{\circ} \mathrm{C}$ against sodium phosphate buffer $(0.05 \mathrm{M}, \mathrm{pH} 6.5)$ then centrifuged at $10000 \mathrm{~g}$ for $10 \mathrm{~min}$ and the supernate was applied to a column $(5 \times 0.7 \mathrm{~cm})$ of protein G-Sepharose 4B (Pharmacia Fine Chemicals). The column was eluted with glycine $(0.05 \mathrm{M}, \mathrm{pH} 2.5)$ and the effluent, monitored at $280 \mathrm{~nm}$, was collected in $1-\mathrm{ml}$ fractions in tubes containing solid Tris $(0.5 \mathrm{~g})$.

\section{Determination of immunoglobulin class}

Ascitic fluids from various cloned hybridomas as well as the MAb purified by affinity chromatography were tested against isotype- and subclass-specific antisera (Meloy, Springfield, VA, USA) by the immunodiffusion method in agar gels. ${ }^{10}$

\section{Sodium dodecyl sulphate-polyacrylamide gel electrophoresis (SDS-PAGE)}

PAGE in the presence of SDS was performed by the method of King and Laemmli. ${ }^{11}$ Briefly, the gel was cast between two plates $(16 \times 16 \mathrm{~cm})$ to a height of $12 \mathrm{~cm}$ with $1 \cdot 0-\mathrm{mm}$ spacers. A stacking gel (acrylamide $3 \% \mathrm{w} / \mathrm{v}$ ) of $4-\mathrm{cm}$ height was applied on top of the analytical gel (acrylamide $10 \% \mathrm{w} / \mathrm{v}$ ). Electrophoresis was performed at $150 \mathrm{~V}$. Cell-surface proteins, either EDTA/NaCl-extracted or DOC-insoluble, were disaggregated at a concentration of $10 \mathrm{mg}$ / $\mathrm{ml}$ in sample buffer (50 mM Tris- $\mathrm{HCl}, \mathrm{pH} 6.8$, containing SDS $2 \% \mathrm{w} / \mathrm{v}$, glycerol $10 \% \mathrm{v} / \mathrm{v}$, bromophenol blue $0 \cdot 1 \% \mathrm{w} / \mathrm{v})$. Gels were stained in Coomassie Brilliant Blue R-2500.2\% $\mathrm{w} / \mathrm{v}$ in methanol : acetic acid : distilled water $(3: 1: 6, v: v: v)$ for $6 \mathrm{~h}$ and destained in several changes of methanol: acetic acid: distilled water $(6: 1: 3, v: v: v)$. BSA (67 Kda), ovalbumin (45 Kda), carbonic anhydrase $(30 \mathrm{Kda})$, trypsinogen $(24 \mathrm{Kda})$, trypsin inhibitor (20 Kda) and lysozyme (14 Kda) were used as marker proteins.

\section{Iso-electric focusing (IEF)}

Analytical IEF was performed in 0.5-mm thin-layer polyacrylamide gels cast between two glass plates. The solutions for gel polymerisation were prepared in $8 \mathrm{M}$ urea as follows: (a) acrylamide $29 \cdot 1 \mathrm{~g}$ made up to $100 \mathrm{ml}$, (b) bisacrylamide $0.9 \mathrm{~g}$ made up to $100 \mathrm{ml}$, (c) ammonium persulphate $10 \mathrm{mg}$ dissolved in $1 \mathrm{ml}$. Acrylamide solution $(3.5 \mathrm{ml})$ was mixed with bisacrylamide $(3.5 \mathrm{ml})$, ampholine (1.5 ml, pH 4-6.5; LKB, Sweden), ammonium persulphate $(0.15 \mathrm{ml}, 10 \% \mathrm{w} / \mathrm{v})$, $8 \mathrm{M}$ urea $(12 \cdot 35 \mathrm{ml})$ and TEMED $(20 \mu \mathrm{l})$. Polymerisation was complete in $2 \mathrm{~h}$. IEF was performed on a flat bed (LKB, Sweden) cooled to $5^{\circ} \mathrm{C}$. The anode and the cathode wicks were saturated with $0.5 \mathrm{M}$ acetic acid and $0.5 \mathrm{M} \mathrm{NaOH}$ respectively. EDTA/NaCl-extracted cell-surface proteins were dissolved in $8 \mathrm{M}$ urea at a concentration of $10 \mathrm{mg} / \mathrm{ml}$. Volumes of $15 \mu \mathrm{l}$ were applied to the gel and focused for $2 \mathrm{~h}$ at a constant power of $25 \mathrm{~W}$ with which a maximum of $2000 \mathrm{~V}$ was not exceeded.

\section{Two dimensional gel electrophoresis (IEF followed by $S D S-P A G E$ )}

After IEF, the gel strip containing protein bands of interest was excised and equilibrated for $1 \mathrm{~h}$ at room temperature with a solution containing glycerol $3.75 \mathrm{ml}$, Tris- $\mathrm{HCl}(0.125 \mathrm{M}, \mathrm{pH} 6.8) 18.75 \mathrm{ml}$, distilled water $15 \mathrm{ml}$, SDS $0.75 \mathrm{~g}$, 2-mercaptoethanol $1.9 \mathrm{ml}$ and a trace of bromophenol blue. The equilibrated strip was placed above a stacking gel $(4.5 \% \mathrm{w} / \mathrm{v})$ and sealed in place with agarose $1 \% \mathrm{w} / \mathrm{v}$. SDS-PAGE was performed according to the procedure of King and Laemmli $^{11}$ with a resolving polyacrylamide gel of $12.5 \% \mathrm{w} / \mathrm{v}$. Proteins in some gels were visualised by the silver staining technique. ${ }^{12}$

\section{Immunoblotting}

Proteins, after being separated by one (1 D) or twodimensional (2 D) electrophoresis, were transferred to nitrocellulose membrane filters by electrophoresis for $16 \mathrm{~h}$ in $25 \mathrm{~mm}$ Tris, $192 \mathrm{~mm}$ glycine (pH 8.3) and methanol $20 \% \mathrm{v} / \mathrm{v}$. The blot was soaked for $2 \mathrm{~h}$ in BSA $3 \%$, w/v in Tween buffer (20 mM Tris, $500 \mathrm{mM} \mathrm{NaCl}$, Tween-20 0.05\% w/v, pH 7.5). It was washed three times with Tween buffer for a total of $1 \mathrm{~h}$ and was later incubated for $2 \mathrm{~h}$ with the purified MAb to the DOCinsoluble cell-surface proteins of $V$. cholerae $\mathrm{O} 1$ (diluted 1 in 100 in Tween buffer). The blot was washed with Tween buffer for $1 \mathrm{~h}$. It was incubated for $1 \mathrm{~h}$ with swine anti-mouse IgG (DAKO; diluted 1 in 500 in Tween buffer) and washed for $1 \mathrm{~h}$ with Tween buffer. It was then incubated for $1 \mathrm{~h}$ with alkaline phosphatase-conjugated rabbit anti-swine IgG (DAKO: 1 in 1000 dilution) and washed for $1 \mathrm{~h}$ with Tween buffer. The blot was visualised by the modified procedure of Blake et al. ${ }^{13}$ Briefly, stock solutions were made as follows: nitroblue tetrazolium (NBT) $1 \mathrm{mg} / \mathrm{ml}$ in $0.1 \mathrm{M}$ ethanolamine buffer, $\mathrm{pH} 9.6$, 5-bromo-4-chloro-3-indolylphosphate (BCIP) $4 \mathrm{mg} / \mathrm{ml}$ in methanol: acetone $(2: 1, v: v)$ and $1 \mathrm{M} \mathrm{MgCl}_{2}$ in water. The reaction mixture contained $1 \mathrm{M} \mathrm{MgCl}_{2}$ $0.2 \mathrm{ml}$, NBT $5 \mathrm{ml}$, BCIP $0.75 \mathrm{ml}$ and was made up to $50 \mathrm{ml}$ with ethanolamine buffer. The reaction was stopped by immersing the blot in distilled water.

\section{Other determinations}

Where specified, ELISAs were also performed against the affinity-purified MAb with EDTA/NaClextracted cell-surface proteins of $V$. cholerae as the coating antigen. Microtitration plates were coated with $100 \mu \mathrm{l}$ of protein $(50 \mu \mathrm{g} / \mathrm{ml}$ in $0.05 \mathrm{M}$ carbonate buffer, $\mathrm{pH}$ 9.6) per well; the remaining steps were identical to those of the ELISA procedure described above. Protein concentrations were measured with 
the Folin-phenol reagent. ${ }^{14}$ Carbohydrates were estimated by the phenol-sulphuric acid method. ${ }^{15}$

\section{Results}

\section{Composition of EDTA extract of $V$. cholerae}

The extraction of $V$. cholerae strain 395 (Ogawa, classical) with EDTA/ $\mathrm{NaCl}$ did not cause any detectable cell lysis when monitored by electronmicroscopy. The extracted material was predominantly protein ( $90 \%$ by weight). When examined by SDS-PAGE, a major protein band of $46-48 \mathrm{Kda}$ and other prominent bands of $61,60,52,40$ and $25 \mathrm{Kda}$ were observed (fig. 1a). The extract was further treated with DOC and the DOC-insoluble pellet contained mainly proteins with no carbohydrate detected by the phenol-sulphuric acid assay. ${ }^{15}$ It consisted of the major protein band of 46-48 Kda (fig. 1b). This material was used as the immunogen in mice to obtain immune spleen cells.

\section{Production and selection of hybridomas}

Fusion of spleen cells from immunised BALB/c a

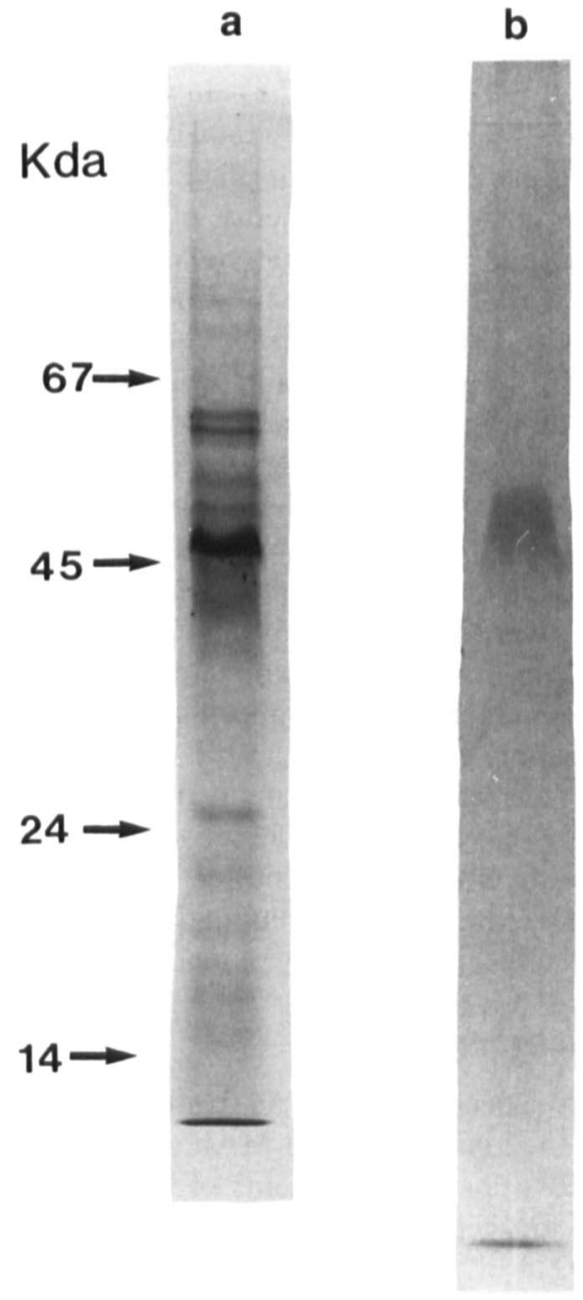

Fig. 1. Analysis of the cell-surface proteins of $V$. cholerae strain 395 (Ogawa, classical) by SDS-PAGE. (a) EDTA/NaCl-extracted cell surface proteins; (b) DOC-insoluble cell-surface proteins. mice yielded many clones viable in HAT medium. These clones were cultured in HT medium and supernates from each were screened by ELISA with the DOC-insoluble cell-surface proteins of $V$. cholerae strain 395 as the coating antigen. It was observed that many clones secreted antibodies initially but they failed to produce antibodies after culture for a few weeks in HT medium. However, four clones were obtained which were stable and continued to secrete antibodies to DOC-insoluble cell-surface proteins when cultured in HT medium over a period of 3-4 weeks. These were recloned three times by limiting dilution and injected intraperitoneally into pristanetreated mice for the production of ascitic fluids. Antibodies from two clones (1C3 G3 and 1C3 G4) produced strong reactions by ELISA whereas the other two clones (1C7 F4, 1C7 G7) gave weaker reactions. All belonged to the $\mathrm{IgG}_{1}$ subclass.

\section{Purification by affinity chromatography}

MAb was purified from the murine ascites produced by one clone (1C3 G3) which gave a strong reaction by ELISA. Affinity chromatography was performed both on protein $A$ and protein $G$ covalently linked to Sepharose 4B. A much higher amount of $\operatorname{IgG}_{1}$ was recovered when recombinant protein G-Sepharose 4B was used as the absorbent (fig. 2). The purified MAb was used in subsequent studies.

\section{Reactivity of the $M A b$ with $L P S$}

The MAb to the DOC-insoluble cell-surface proteins of $V$. cholerae strain 395 (Ogawa), purified by affinity chromatography on recombinant protein G-Sepharose 4B, was tested against homologous $V$. cholerae LPS by ELISA. Microtitration plates were coated with $V$. cholerae LPS (Ogawa). An affinity-purified polyclonal anti-LPS (Ogawa) was used as the positive control. The MAb preparation did not contain any detectable activity against $V$. cholerae $L P S$ whereas the polyclonal anti-LPS serum produced a positive reaction (data not shown).

\section{Reactivity of the MAb towards homologous and heterologous cell-surface proteins of $V$. cholerae}

It has been reported that $V$. cholerae contains cellsurface-protein antigens which are common to both the biotypes (classical and El Tor) and the serotypes (Ogawa and Inaba) of $V$. cholerae. ${ }^{1,3,7}$ The crossreactivities of the purified MAb to the DOC-insoluble cell-surface proteins of $V$. cholerae strain 395 (Ogawa, classical) with EDTA/NaCl-extracted cell-surface proteins from the heterologous strains 569B (Inaba, classical), W-13021 (Ogawa, El Tor) and N-16961 (Inaba, El Tor), as well as the homologous strain, were determined by ELISA. The MAb displayed almost equal reactivity towards these preparations with titres c. 10000 . 


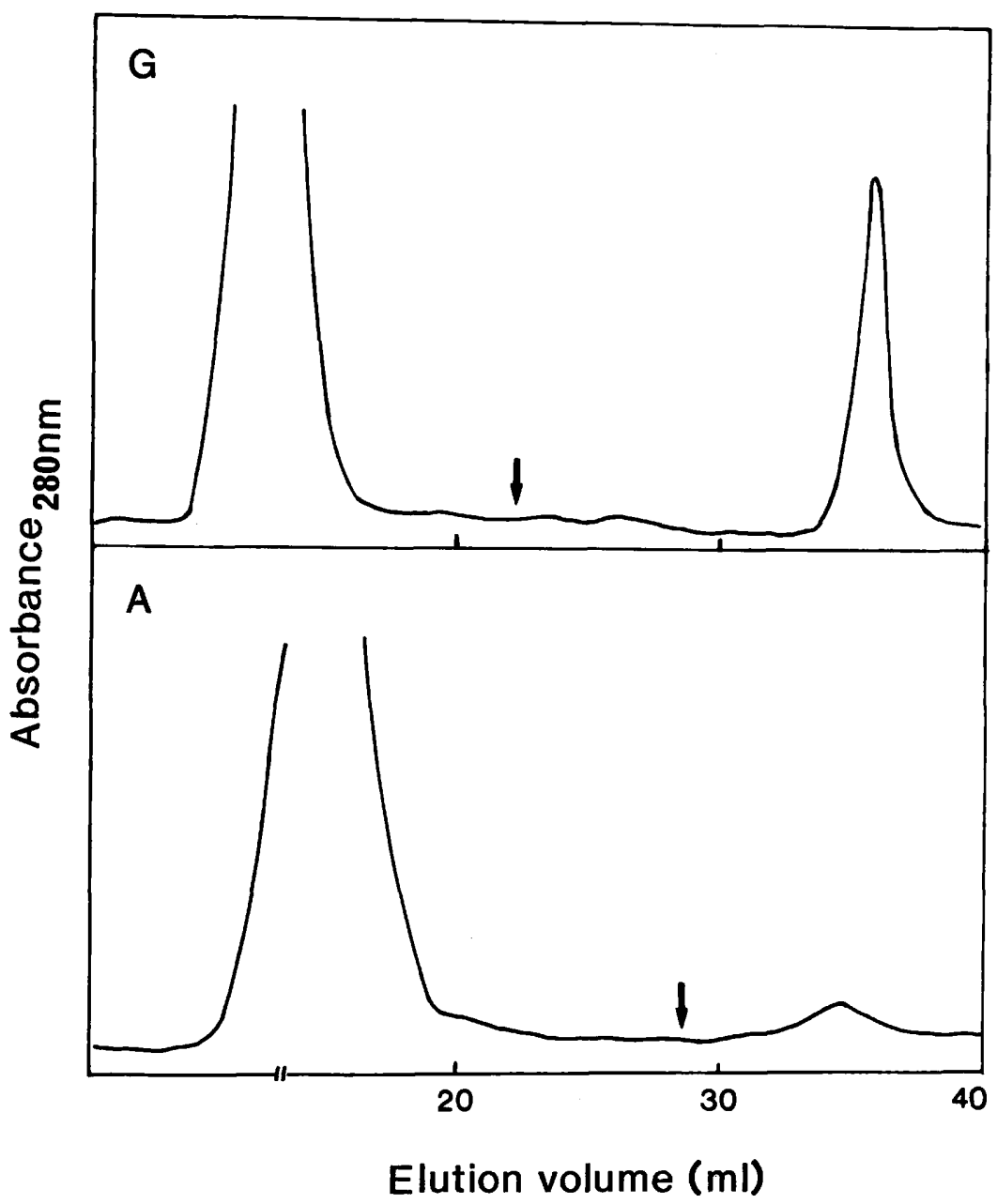

Fig. 2. Isolation of the $M A b\left(\operatorname{IgG}_{1}\right)$ from murine ascitic fluid by chromatography on recombinant protein G-Sepharose $4 B(G$; top) and protein A-Sepharose 4B (A; bottom) columns. Arrows indicate the addition of elution buffer.

\section{Demonstration of the specific protein band by immunoblotting}

The EDTA/NaCl-extracted cell-surface proteins from $V$. cholerae strain 395 (Ogawa, classical) were separated by SDS-PAGE and transferred on to nitrocellulose. To determine whether the purified MAb reacted with the protein band at $46-48 \mathrm{Kda}$, the blot was incubated with the MAb and subsequently developed by ELISA. Although the EDTA-extracted material contained several protein bands (fig. 1a), only the major protein band at $46-48 \mathrm{Kda}$ reacted with the $\mathrm{MAb}$ (fig. 3).

\section{Two dimensional electrophoretic analysis}

Two dimensional (2D) electrophoresis (IEF in the first dimension and SDS-PAGE in the second dimension) has a high resolving power. IEF in the first dimension was performed in the presence of $8 \mathrm{M}$ urea. The EDTA/NaCl-extracted cell-surface proteins were resolved into several protein bands in the $\mathrm{pI}$ range 46.5 (fig. 4a). The majority of the proteins were focused in the pI range $5 \cdot 0-5 \cdot 5$.

Before the second dimension electrophoresis, the gel strip containing proteins after IEF in the first dimension was equilibrated at room temperature with the equilibration buffer for SDS-PAGE. The electrophoretic pattern was visualised by silver staining (fig. 4b). Another, unstained, 2D gel was electroblotted and visualised by immunoblotting with the purified MAb. Although the 2D gel, developed by the silver staining technique, displayed numerous bands (fig. $4 b)$, the MAb reacted with the protein complex appearing at $46-48 \mathrm{Kda}$ (fig. 5). The spot appeared to consist of two closely-spaced adjacent protein bands. A faint band was also detected against a higher mol. wt protein band of $c .95 \mathrm{Kda}$. Since proteins, separated by IEF, were treated at room temperature with SDSequilibration buffer, it is possible that the higher mol. wt protein might represent the dimer of the protein complex at $46-48 \mathrm{Kda}$.

\section{Discussion}

Initial attempts were made to purify the MAb on a protein A-Sepharose 4B column. Alkaline buffers of high ionic strengths were used to bind the antibody to protein A. ${ }^{16}$ However, the amount of $\mathrm{IgG}_{1}$ recovered was rather small and the use of high salt concentrations 


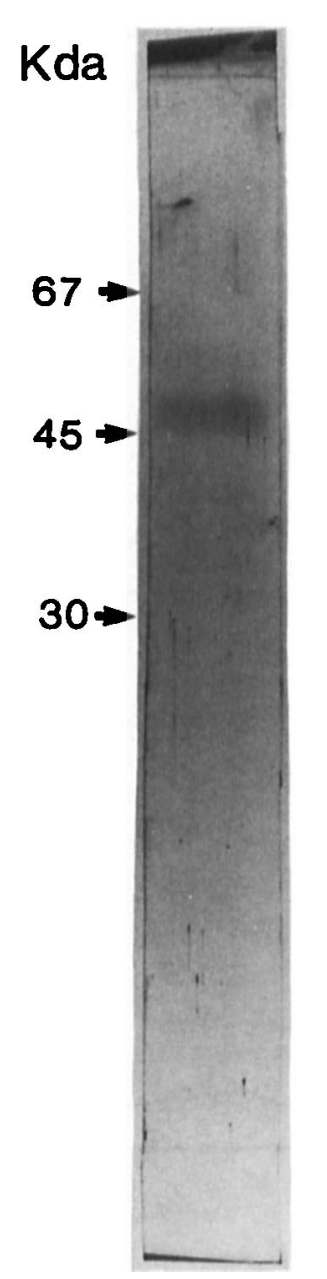

Fig. 3. Immunoblot showing the reactivity of the MAb to 46-48$\mathrm{Kda}$ DOC-insoluble cell-surface proteins with EDTA/ $\mathrm{NaCl}-\mathrm{ex}$ tracted cell-surface proteins of $V$. cholerae strain 395 separated by (1D) SDS-PAGE.

is not desirable, as it may lead to non-specific adsorption to the matrix. In contrast, when an affinity matrix containing protein $\mathrm{G}$ was used, a large amount of $\mathrm{IgG}_{1}$ was recovered. The recombinant protein $\mathrm{G}$ used in this investigation was devoid of the albuminbinding region present in native protein $G$, a bacterial cell-wall protein extracted from group $G$ streptococci. ${ }^{17}$ Although murine MAbs from ascitic fluids can be separated by DEAE Affi-gel blue chromatography, the eluted antibodies have been found to contain other impurities. ${ }^{18}$ Considering all these factors, chromatography on protein G-Sepharose 4B should be the method of choice for the purification of murine $\mathrm{IgG}_{1}$ MAbs.

By immunoblotting it was observed that the MAb had reacted with the major cell-surface protein band of $V$. cholerae of $46-48 \mathrm{Kda}$. It also produced a positive reaction, as judged by ELISA, to the cell-surface proteins from both biotypes (classical and E1 Tor) and both serotypes (Ogawa and Inaba) of $V$. cholerae. The $\mathrm{MAb}$ reacted with the cell-surface proteins whether these had been equilibrated with SDS either at room temperature or heated at $100^{\circ} \mathrm{C}$. When cell-surface proteins were analysed by $2 \mathrm{D}$ electrophoresis (IEF and SDS-PAGE) the proteins were treated with SDS- a

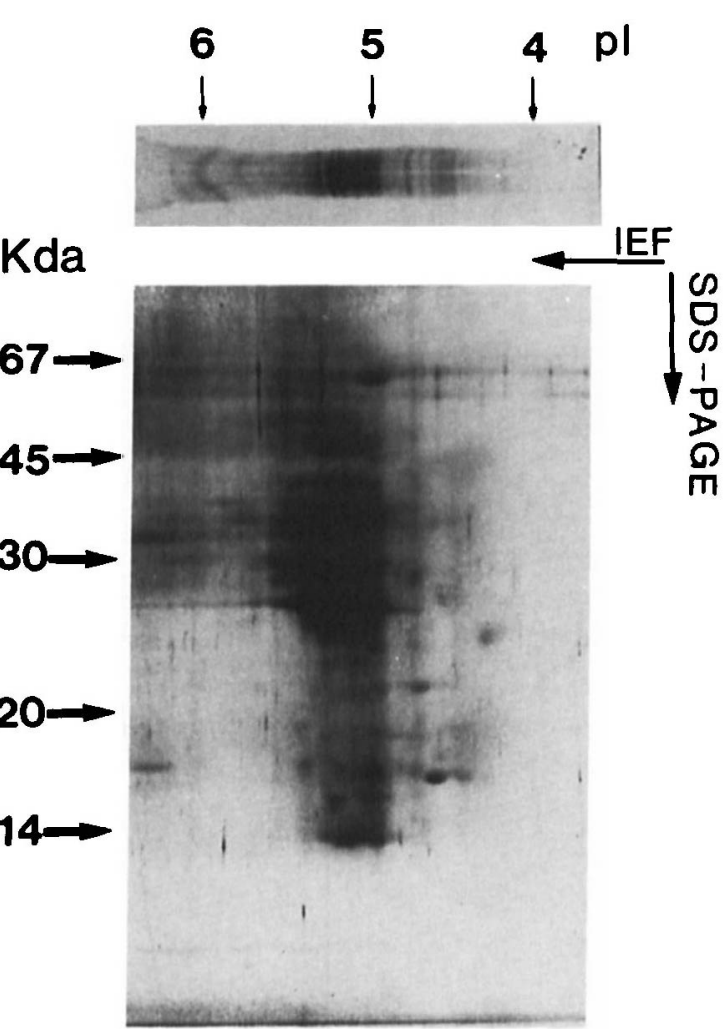

Fig. 4. Separation of the EDTA-NaCl-extracted cell-surface proteins of $V$. cholerae strain 395 by $2 \mathrm{D}$ gel electrophoresis. In the first dimension, proteins were separated by IEF and bands were visualised by staining with Coomassie Brilliant Blue R250 (a). They were subjected to SDS-PAGE in the second dimension under reducing conditions and bands were visualised by silver staining (b).

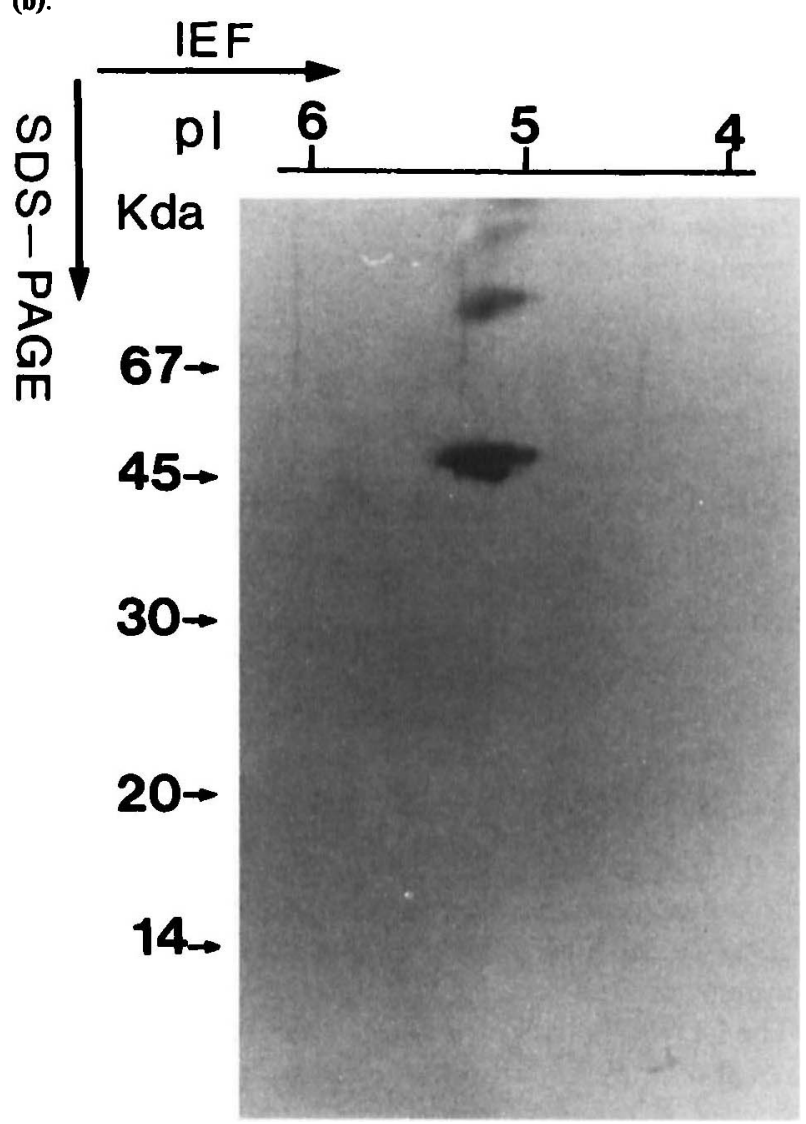

Fig. 5. Immunoblot showing the reactivity of the MAb to the DOCinsoluble cell-surface proteins against EDTA/NaCl-extracted cellsurface proteins of $V$. cholerae strain 395 separated by 2D gel electrophoresis. 
equilibration buffer at room temperature. The MAb reacted with the protein band at $46-48 \mathrm{Kda}$ but when stained by silver nitrate, this band was not very prominent. This confirms a previous finding that the major band of 46-48 Kda in 1D SDS-PAGE became prominent when cell-surface proteins were heated with SDS above $60^{\circ} \mathrm{C} .{ }^{1}$

The spot on the 2D immunoblot at $46-48 \mathrm{Kda}$, visualised with the MAb, appeared to consist of two closely spaced and immunologically cross-reactive proteins at $46-48 \mathrm{Kda}$. In immunoblots of proteins separated by SDS-PAGE, it was not possible to distinguish between these bands as they overlapped. These results indicate the superior resolving power of 2D electrophoresis compared to that offered by 1D SDS-PAGE. Preliminary results suggest that the 46-48 Kda protein band is resistant to the action of proteases such as V8 protease from Staphylococcus aureus. Gram-negative bacteria possess transmembrane channel-forming proteins, known as porins, which are resistant to digestion by several proteases. ${ }^{19-21}$ Escherichia coli strain K12 contains $\mathrm{OmpF}$ and $\mathrm{OmpC}$ porins which share common features: they have very similar amino-acid compositions and mol. wts and they are immunologically cross-reactive. ${ }^{22-24}$ Although porins of $V$. cholerae

\section{References}

1. Kabir S. Composition and immunochemical properties of outer membrane proteins of Vibrio cholerae. J Bacteriol 1980; 144: 382-389.

2. Kabir S. Antigenic analysis of Vibrio cholerae 01 by crossedimmunoelectrophoresis. Zentralbl Bakteriol Mikrobiol Hyg 1989; A 270: 361-372.

3. Kabir S. Composition and immunochemical properties of the ceil surface proteins of Vibrio cholerae. J Gen Microbiol 1986; 132: 2235-2242.

4. Richardson $\mathrm{K}$, Parker $\mathrm{CD}$. Identification and characterization of Vibrio cholerae surface proteins by radioiodination. Infect Immun 1985; 48: 87-93.

5. Kabir S. Immunological responses of rabbits to various somatic and secreted antigens of Vibrio cholerae after intraduodenal inoculation. J Med Microbiol 1987; 24: 29-40.

6. Sciortino CV, Yang Z, Finkelstein RA. Monoclonal antibodies to outer membrane antigens of Vibrio cholerae. Infect Immun $1985 ; 49: 122-131$.

7. Kabir $\mathrm{S}$. The serological properties of the cell surface proteins of Vibrio cholerae. J Gen Microbiol 1983; 129 : 2199-2206.

8. Schrier M, Köhler G, Hengartner H, Berek C, Trucco M, Forni L. Hybridoma techniques, 1st edn. Cold Spring Harbor, New York, Cold Spring Harbor Laboratory. 1980:5.

9. Oi VT, Herzenberg LA. Immunoglobulin-producing hybrid cell lines. In: Mishell BB, Shiigi SM (eds) Selected methods in cellular immunology. New York, W. H. Freeman and Company. 1980: 351-372.

10. Ouchterlony Ó. Antigen-antibody reactions in gels. Acta Pathol Microbiol Scand 1949; 26: 507-515.

11. King J, Laemmli UK. Polypeptides of the tail fibres of bacteriophage T4. J Mol Biol 1971; 62: 465-477.

12. Kabir $\mathrm{S}$. Charge heterogeneity of cholera toxin and its subunits. FEMS Microbiol Lett 1986; 37: 155-162.

13. Blake MS, Johnston KH, Russell-Jones GJ, Gotschlich EC. A rapid, sensitive method for detection of alkaline phosphatase-conjugated anti-antibody on Western blots. Anal Biochem 1984; 136: 175-179. have not been identified, the two closely spaced protein bands appearing in the mol. wt range 46$48 \mathrm{Kda}$ might be the porins of $V$. cholerae. Thus, like porins of $E$. coli, they are (i) resistant to the action of proteases, (ii) very similar in mol. wt and (iii) immunologically cross-reactive.

The MAb produced in this investigation was devoid of any activity towards LPS. This provides a major advantage over polyclonal sera because membrane protein preparations can be contaminated with LPS components which are strong immunogens. Previously, polyclonal sera had to be absorbed with $V$. cholerae LPS to be made specific for OMPs. ${ }^{1}$ This problem has now been overcome.

The OMPs of $V$. cholerae have been studied by SDSPAGE in several laboratories and anomalous banding patterns in Coomassie-stained gels in the region of 40$50 \mathrm{Kda}$ have been reported. ${ }^{1,4,25,26}$ However, different laboratories have used different SDS-PAGE conditions for analysis of $V$. cholerae OMPs. Therefore, it is quite possible that the same protein might have been reported to possess different mol. wts. This problem can be overcome by preparing MAbs against the protein components and comparing results from various laboratories on the basis of specific reactions of the proteins with these MAbs.
14. Lowry OH, Rosebrough NJ, Farr AL, Randall RJ. Protein measurement with the Folin phenol reagent. $J$ Biol Chem 1951; 193: 265-275.

15. Dubois M, Gilles KA, Hamilton JK, Rebers PA, Smith F. Colorimetric method for determination of sugars and related substances. Anal Chem 1956; 28: 350-356.

16. Ohlson S, Wieslander J. High-performance liquid affinity chromatographic separation of mouse monoclonal antibodies with protein A silica. J Chromatogr 1987; 397: 207-212.

17. Björck L, Kronvall G. Purification and some properties of streptococcal protein $\mathrm{G}$, a novel IgG-binding reagent. $J$ Immunol 1984; 133: 969-974.

18. Bruck C, Portelle D, Glineur C, Bollen A. One-step purification of mouse monoclonal antibodies from ascitic fluid by DEAE Affi-gel blue chromatography. J Immunol Methods 1982: 53: 313-319.

19. Rosenbusch JP. Characterization of the major envelope protein from Escherichia coli. J Biol Chem 1974; 249: 8019-8029.

20. Nakae T. Outer membrane of Salmonella. Isolation of protein complex that produces transmembrane channels. $J$ Biol Chem 1976; 215: 2176-2178.

21. Reithmeier RAF, Bragg PD. Molecular characterization of a heat-modifiable protein from the outer membrane of Escherichia coli. Arch Biochem Biophys 1977; 178: 527-534.

22. Overbeeke N, Van Scharrenburg G, Lugtenberg B. Antigenic relationships between pore proteins of Escherichia coli $\mathrm{K} 12$. Eur J Biochem 1980; 110 : 247-254.

23. Hofstra $\mathbf{H}$, Dankert J. Porin from the outer membrane of Escherichia coli: immunological characterization of native and heat-dissociated forms. J Gen Microbiol 1981; 125: 285-292.

24. Nikaido $\mathrm{H}$, Wu HCP. Amino acids sequence homology among the major outer membrane proteins of Escherichia coli. Proc Natl Acad Sci USA 1984; 81 : 1048-1052.

25. Sciortino CV, Finkelstein RA. Vibrio cholerae expresses ironregulated outer membrane proteins in vivo. Infect Immun 1983; 42: 990-996.

26. Kelley JT, Parker CD. Identification and preliminary characterization of Vibrio cholerae outer membrane proteins. $J$ Bacteriol 1981; 145 : 1018-1024. 
